\title{
Analisis Tingkat Keuntungan Petani Dan Pedagang Jagung Kuning (Zea mays) Di Kecamatan Bontotiro Kabupaten Bulukumba
}

\author{
Dahniar $^{1}$, Makmur $^{2}$, I Susanti $^{3}$ \\ ${ }^{1}$ Program Studi Agribinis Universitas Sulawesi Barat \\ ${ }^{2}$ Program Studi Agribinis Universitas Sulawesi Barat \\ ${ }^{3}$ Program Studi Peternakan Universitas Sulawesi Barat \\ a_dahniar@yahoo.com \\ makmur.unsulbar@gmail.com \\ irmasusanti227@gmail.com
}

\begin{abstract}
Abstrak
Program sektor pertanian diarahkan untuk menghubungkan agribisnis yang mengakar kuat di pedesaan serta mendukung pengembangan wilayah pengembangan wilayah sektor pertanian didasarkan atas keterpaduan dalam suatu sistem berorientasi pasar, memanfaatkan sumberdaya secara optimal, dikelola secara profesional dengan didukung oleh sumberdaya yang berkualitas. Metode penelitian yang digunakan adalah metode survei. Populasi dalam penelitian ini adalah senua petani jagung kuning yang ada di Kecamatan Bontotiro dengan menetapkan 3 desa yaitu Desa Batang, Desa Bontotangga dan Desa Bontomarannu. Pengambilan sampel untuk petani dengan jumlah 20 orang petani jagung kuning pada masing-masing desa yang ada di Kecamatan Bontotiro. Selain dari responden, data diambil pula dari instansi printah dan pustaka. Data tersebut selanjutnya dianalisis dengan menggunakan analisi pendapatan, $\mathrm{R} \backslash \mathrm{C}$ - ratio dan $\mathrm{B} \backslash \mathrm{C}$ ratio, serta analisis margin dan pemasaran dan keuntungan. Hasil penelitian ini menunjukkan bahwa tingkat pendaptan petani jagung kuning dari usahataninya sebesar Rp. 1.438.967.794/musim/tanam/hektar dengan R/C-ratio sebesar 3,2 serta B/C-ratio sebesar 2,2. Besarnya margin keunungan yang diterima masing-masing lembaga pemasaran yang terbesar diterima oleh pedagang pengecer sebesar Rp. 400/kg jagung pipalans, pedagang pengumpul sebesar Rp. 300/kg jagung pipilan dan pedagang besar Rp.250/kg jagung pipilan.
\end{abstract}

Keywords : Analisis, petani, jagung, Bontotiro

\section{Pendahuluan}

Paradigma baru pembangunan indonesia lebih dioreintasikan pada sektor pertanian sebagai sumber utama pertumubuhan ekonomi melalui peningkatan kapasitas lokal, karna selama ini sektor pertanian telah terbukti tahan terhadap goncangan krisis ekonimi. Pembangnan sektor pertanian apabila tidak berhasil maka berdampak negativ terhadap pembangunan secara keseluruham sejarah pembangunan indonesia menjunjukkan bahwa masalah keadaan pangan (Food save) sangat erat kaitannya dengan stabilitas ekoomi, biaya hidup dari stabilitas politik nasional (Saragih, 2001).

Badan Litbang (1999) merumuskan bahwa pembangunan pertanian jangka panjang dihadapkan pada berbagai tantangan yang cukup berat. Tantangan tersebut antara lain pemenuhan kecukupan pangan, persaingan dalam pasar global, mencari alternatif sumber pertumbuhan ekonomi, peningkatan kesejahteraan masyarakat pedesaan dan optimalisasi pemanfaatan sumberdaya lahan. Sewajarnya bahwa pembangunan pertanian seyogyanya dilaksanakan merata diseluruh penjuru tanah air, agar kendalan

Agrovital | Jurnal Ilmu Pertanian Universitas Al Asyariah jarak dan kesulitan dalam pendistribusian produknya dapat diatasi.

Program sektor pertanian diarahkan untuk menghubungkan agribisnis yang mengakar kuat di pedesaan serta mendukung pengembangan wilayah pengembangan wilayah sektor pertanian didasarkan atas keterpaduan dalam suatu sistem berorientasi pasar, memanfaatkan sumberdaya secara optimal, dikelola secara profesional dengan didukung oleh sumberdaya yang berkualitas. Teknologi tepat guna, berwawasan lingkungan dan kelembagaan yang kokoh. Dengan dikembangkannya sistem agbisnis secara sehat (ekonomi,sosial,kelembagaan, lingkungan) maka sumberdaya alam dan ekosistem pertanian setempat, yaitu melaui dihasilkannya uk-pk pertanian yang berdaya saing tinggi di pasar lokal, mestik mmauoun global. Agribisnis berperan penting dalam pembangunan nasional karena sifat alam indonesia sebagai negara agraris.

Setidaknya, terdapat beberapa alasan keperluan untuk meletakkan harapan pada kegiatan agribisnis dalam pembangunan ekonomi nasioanl guna menyongsong era agroindustrialisasi. Menurut Saragih (2002), alasan tersebut adalah : (1) harus 
senantiasa mencari sumber pertumbuhan antar sektor, (2) secara nasional ada keperluan mendesak untuk meyiapkan lapangan kerja baru dalam menghadapi tambahan jumlah angkatan kerja yang harus meningkat setiap tahun, (3) secara nasional juga mempunyai kepentingan untuk menciptakan landfasan yang kokoh bago keperluan ekspor non migas yang berakar pada keunggulan komperatif, (4) pentingnya pangsa produsen bahan mentah terutama dalam meraih pendaopatan dari proses nilai tambahan yang perlu diperbesar, dan (5) kegiatan agribisnis sangat mengandalkan keberadaan sumberdaya alam pertanian yang mempunyai karakteristik dasar sebagai sumberdaya yang senantiasa dapat deiperbaharui.

Diyakini bahwa kegiatan usahatani yang dominan berada di pedesaan telah membangkitkan dan meningkatkan perekonomian.hal ini karena pengelolaan usahatani dengan menggunakan pendekatan agribisnis semakin giat dilaksanakan, dengan harapan bahwa usahatani tersebut harus dikelola dengan berbagai sumberdaya yang cukup efektif dan efesien. Menurut saragih (2002), tanpa usahatani yang efektif dan efisien mustahil akan dapat dibangun suatu sistem agrebisnis atau suatu proses peningkatan nilai tambah sunberdaya petani yang lebih kuat. Teknologi yang digunakan untuk itu tidak hanya mencakup bidang teknis usahatani, namun juga mencakup teknologi pengolahan dan distribusi, sehingga menghasilkan produk pertanian yang berdaya saing tinggi di pasaran dan berdampak positif terhadap perekonomian massyarakat (pedesaan) setempat.

Upaya untuk menjadikan tanaman jagung kuning sebagai suatu sumber perekonomian baru adalah melalui pengembangan kawasan yang memenuhi skala usaha ekonomi dengan pendekatan sistem agribisnis. Kontribusi sektor pertanian dalam menyiapkan sumberdaya manusia diawali dengan pemenuhan kebutuhan bahan pangan yang kaya akan sumber karbohidrat dan vitamin A, untuk mencermati kandungan dan komposisi kimia tersebut, jagung selain merupakan sumber kalori juga pensuplai nutrisi untuk memperoleh keseimbangan gizi penduduk.

Program peningkatan produksi pangan tetap dirahkan untuk mengupayakan pelestarian swasembada beras disamping pencapaian swasembada jagung yang telah direncanakan pada tahun 1998. Permintaan pasar dalam negeri dan peluang ekspor komoditi jagung cenderung meningkat dari tahun ke tahun. Produksi jagung nassional sampai sekarang belum sepenuhnya mampu memenuhi kebutuhan sehingga masih dilakukan impor jagung. Jagung impor pada tahun 2000 mencapai 1.264.757 ton. Sejalan dengan pertambahan penduduk dan perkembangan industry pakan ternak akibat pergeseran pola makan masyarakat kearah pemenuhan kebutuhan protein hewani, maka secara langsung atau tidak langsung sangat berpengaruh terhadap perkembangan usahatani jagung. Kebutuhan jagung untuk pakan meningkat dari 1.706.000 ton pada tahun 1990 menjadi 4.085.000 ton pada tahun 1997 (Warison, 1998).

Peranan Sulawesi Selatan merupakan provinsi di Indonesia cukup berperan penting sebagai salah satu sentra pengembangan jagung kuning. Hal ini sangat memungkinkan karena Sulawesi Selatan memiliki lahan sekitar 450.000 ha yang cukup potensial untuk tanaman jagung. Aral tersebut sebagian menyebar pada beberapa kabupaten yang merupakan pusat atau sentra produksi. Misalnya Kabupaten Bone, Jeneponto, Bantaeng, Soppeng, Takalar, Gowa, dan Sinjai. Sementara itu Kabupaten Bulukumba merupakan salah satu daerah pengembangan jagung yang mampu menghasilkan jagung kuning (hibride) 3-5 ton per hektar (Dinas Pertanian Tanaman dan Hortikultura Sulawesi Selatan, 2004).

Kabupaten Bulukumba memiliki luas lahan yang potensial untuk tanaman jagung kuning dengan luas areal pertanaman 35.059 ha. Untuk mengetahui luas areal, produksi dan produktivitas jagung kuning di Kabupaten Bulukumba dapat dilihat pada tabel 1.

Tabel 1.Perkembangan Lusa Lahan, dan Produktivitas Jagung Kuning Ditiap Kecamatan di Kabupaten Bulukumba Pada Tahun 2004.

\begin{tabular}{ccccc}
\hline No & Kecamatan & $\begin{array}{c}\text { Lahan } \\
\text { (ha) }\end{array}$ & $\begin{array}{c}\text { Produksi } \\
\text { (ton) }\end{array}$ & $\begin{array}{c}\text { Produktivitas } \\
\text { (kw/ha) }\end{array}$ \\
\hline 1 & Ujung Loe & 50 & 150 & 30 \\
\hline 2 & Ujung Bulu & 6.840 & 21.204 & 31 \\
\hline 3 & Herlang & 6.200 & 21.700 & 30 \\
\hline 4 & Kajang & 7.076 & 24.766 & 35 \\
\hline 5 & Rilau Ale & 2.040 & 5.916 & 29 \\
\hline 6 & Gantarang & 2.000 & 7.000 & 30 \\
\hline 7 & Kindang & 200 & 620 & 31 \\
\hline 8 & Bulukumpa & 1.200 & 3.600 & 30 \\
\hline 9 & Bonto & 2.250 & 6.750 & 29 \\
\hline 10 & Bonto Tiro & 7.203 & 20.889 & 30 \\
\hline
\end{tabular}




\section{Jumlah $\quad 35.059$}

Sumber: Dinas Tanaman Pangan dan Hortikultural Kabupaten Bulukumba, Tahun 2004.

Tabel 1 dapat dilihat bahwa Kecamatan Kajang menghasilkan produksi yang paling tinggi yaitu 24.766 ton dengan luas lahan 7.076 ha serta produksivitasnya $35 \mathrm{kw} / \mathrm{ha}$ atau 3,5 ton/ha. Sedangkan Kecamatan yang paling sedikit produksinya adalah Ujung Bulu dengan total produksi 150 ton dengan luas lahan 50 ha dan produksivitasnya $30 \mathrm{kw} / \mathrm{ha}$.

Selain tingkat produksi dan luas lahan, perkembangan harga jual petani di desa juga perlu diperhatikan dalama rangka peningkatan produksi sehingga dapat pula meningkatkan pendapatannya.

\section{Metodologi Penelitian}

Penelitian ini dilaksanakan di Kecamatan Bontotiro, Kabupaten Bulukumba. Lokasi penelitian ini ditentukan secara purpossive dengan memilih Kecamatan Bontotiro dengan menetapkan 3 Desa yaitu Desa Batang, Desa Bontoanggan, dan Desa Bontomarannu. Lokasi ini dipilih dengan pertimbangan bahwa kecamatan tersebutmempunyai potensial untuk dikembangkan jagung kuning dengan mempunyai luas lahan dan produktivitas yang tinggi dan sebagian besar masyarakat Kecamatan Bontotiro makanan pokoknya adalah jagung. Penelitian ini telah dilaksanakan pada bulan Desember 2004 sampai dengan bulan Februari 2005.

Jenis dan sumber data yang digunakan dalam penelitian ini adalah sebagai berikut : Data primer adalah data yang diperoleh langsung dari hasil wawancara dengan petani responden dan pedagang jagung kuning. Data sekunder adalah data yang diperoleh melalui studi kepustakaan dan dokumentasi pada instansi yang ada kaitannya dengan penelitian seperti Dinas Tanaman Pangan dan Hortikultura, Kantor Biro Statidtik dan Bappeda yang ada di Kabupaten Bulukumba.

Populasi dan penelitian ini adalah petani yang mengusahakan komoditas jagung kuning dan pedagang yang memasarkan jagung kuning di kecamatan Bontotiro Kabupaten Bulukumba.

Pemilihan sampel (Responden terpilih) dilakukan dengan tahapan sbb: Pemilihan sampel kecamatan didasarkan sebagai salah satu daersh sentra pembangunan jagung kuning di kabupaten Bulukumba. Pemilihhan sampel desa, dipilih beberapa desa sebagai sentra pembangunan jagung kuning.
Pemilihan sampel petani dilakukan secara acak (simple random sampling) dimana seluruh anggota populasi memiliki kemungkinan yang sama untuk terpilih menjadi sampel. Ditetapkan jumlah sampel sebanyak 60 orang petani dan 10 orang pedagang jagung kuning.

Pengumpulan data yang dilakukan dalam penelitian ini adalah dengan cara : Observasi, yaitu pengumpulan data melalui pengamatan langsung terhadap kegiatan responden dengan maksuduntuk memperoleh data primer. Wawancara, yaitu pengumpulan data melalui tanya jawab dengan responden yang menggunakan daftar pertanyaan atau kuesioner untuk memperoleh data primer dan sekunder. Dokumentasi, yaitu pengumpulan data melalui jurnal-jurnal, hasil-hasil penelitian terdahul, dan buku-buku literatur yang ada kaitannya dengan penelitian guna memperoleh data sekunder.

Untuk menguji hipotesis, maka analisis yang dilakukan adalah sebagai berikut : Hipotesis pertama digunakan analisa pendapatan, yaitu untuk mengetahui tingkat pendapatan petani dengan rumus pendapatan sebagai berikut :

$$
\begin{aligned}
& \pi=\text { TR-TC } \\
\operatorname{dimana}: \pi & =\text { Pendapatan } \\
\text { TR } & =\text { Total Revenue } \\
\text { TC } & =\text { Total Cost }
\end{aligned}
$$

Untuk mengetahui layak atau tidaknya usahatani jagung kuning ini dugunakan abnalisis R/C- Ratio dengan rumus (Soekartawi, 2002).

$$
\mathrm{R} / \mathrm{C}=\frac{\text { Total Revenue }}{\text { Total Cost }}
$$

Dengan syarat Jika :

$\mathrm{R} / \mathrm{C}$ ratio $>1$, maka usahatani jagung kuning menguntungkan.

$\mathrm{R} / \mathrm{C}$ ration $=1$ maka usaha tani jagung kuning tidak untung dan tidak rugi (Impas)

$\mathrm{R} / \mathrm{C}$ ratio $<1$ maka usahatani jagung kuning tidak menguntungkan.

Hipotesis kedua digunakan analisis margin pemasaran dan keuntungan dengan rumus :

$$
\mathbf{M}=\mathbf{H} \mathbf{j}-\mathbf{H b}
$$

Dimana: $\mathrm{M}=$ Margin Pemasaran

$$
\mathrm{Hj}=\text { Harga Jual }
$$$$
\mathrm{Hb}=\text { Harga beli }
$$

\section{Hasil Dan Pembahasan}

\section{Identitas Petani}




\section{A. Identitas Responden}

Berdasarkan suatu usaha sangat dipengaruhi oleh aspek lingkungan diri petani atau identitas responden yang mencangkup hal-hal seperti : Umur, Tingkat pendidikan, Jumlah tanggungan keluarga, dan pengalaman usaha tani serta luas areal pertanaman.

\section{Umur Petani}

Umur petani dipengaruhi oleh kemampuan fisik bekerja dan cara berfikir, pada umumnya petani yang berumur muda dan sehat mempunyai fisik yang lebih baik dari pada petani yang lebih tua, petani muda juga lebih cepat menerima hal-hal yang baru atau inovasi baru. Hal ini di sebabkan karna petani muda lebih berani menanggung resiko sedangkan petani yang berumur tua mempuanyai kemampuan kerjanya relatif menurun dan mempunyai kapasitas pengelolaan yang lebih baik dan berhati-hati dalam bertindak, karna sudah mempunyai banyak pengalaman dalam mengelola usaha taninya.

Umur petani responden bervariasi antara petani yang satu dengan petani yang lainnya, ada yang masih muda tetapi ada juga yang sudah tua. Namun umur bagi mereka bukan suatu kendala dalam mengelola usaha taninya. Menurut Yasin (1991), bahwa yang termasuk umur produktif secara ekonomi yaitu umur petani 60 tahun. Untuk lebih mengetahui umur petani responden dapat dilihat pada tabel 6 .

Tabel 2. Jumlah petani menurut kelompok umur petani jagung kuning di kecamatan Bontotiro, Kabupaten Bulukumba, 2005

\begin{tabular}{cccc}
\hline No & $\begin{array}{c}\text { Kelompok } \\
\text { Umur (Tahun) }\end{array}$ & $\begin{array}{c}\text { Jumlah } \\
\text { Petani } \\
(\text { Orang) }\end{array}$ & $\begin{array}{c}\text { Persentasi } \\
(\%)\end{array}$ \\
\hline 1 & $25-33$ & 12 & 20,00 \\
\hline 2 & $34-42$ & 17 & 29,33 \\
\hline 3 & $43-51$ & 15 & 25,00 \\
\hline 4 & $52-60$ & 10 & 16,67 \\
\hline 5 & $61-70$ & 6 & 10,00 \\
\hline & Jumlah & 60 & 100,00 \\
\hline
\end{tabular}

Agrovital | Jurnal Ilmu Pertanian Universitas Al Asyariah
Pada tabel 2 nampak bahwa umur petani responden bervariasi. Umur yang dominan yaitu kelompok umur 34-42 tahun sebanyak 17 orang atau 28,33 persen, kelompok umur 43-51 tahun sebanyal 15 orang atau 25,00 persen, dan kelompok umur 25-33 tahun sebanyak 12 orang atau 20,00persen serta kelompok umur 52-60 tahun sebanyak 10 orang atau 16,67 persen.

Adapun petani yang berumur 61-70 tahun keatas sebanyak 6 orang atau 10,00 persen ini digolongkan umur kurang produktif hal ini disebabkan pada umur tersebut kondisi fisik petani sudah mulai menurun dalam aktifitasusaha tanimya. Pada hasil penelitian dilapangan di peroleh umur paling muda adalah 25 tahun dan umur yang paling tua adalah petani yang berumur 70 tahun. Untuk melihat hubungan umur petani dengan pendapatan maka dilihat pada tabel 3

Tabel 3. Hubungan antara umur dengan pendapatan petani jagung kening di kecamatan Bontotiri, Kabupaten Bulukumba, 2005.

\begin{tabular}{cccccc}
\hline \multirow{3}{*}{ No } & $\begin{array}{c}\text { Kelompok } \\
\text { umur } \\
\end{array}$ & \multicolumn{5}{c}{ Pendapatan Responden } \\
\cline { 3 - 6 } & Tahun) & Rendah & Sedang & Tinggi & Jumlah \\
\hline 1 & $25-33$ & 8 & 2 & 2 & 12 \\
\hline 2 & $34-42$ & 9 & 5 & 3 & 18 \\
\hline 3 & $43-51$ & 9 & 4 & 2 & 16 \\
\hline 4 & 560 & 4 & 5 & 1 & 8 \\
\hline 5 & $61-70$ & 4 & 2 & - & 6 \\
\hline & Total & 34 & 18 & 8 & 60 \\
\hline
\end{tabular}

Dari Tabel 3 menunjukkan bahwa kelompok umur 34-42 tahun sebanyak 3 orang atau 5,00 persen berpendapatan tinggi, kelompok umur 34-42 tahun dan 52-60 tahun masing-masing 5 orang atau 8,33 persen berpendapatan, sedang, sedangkan kelompok umur 34-42 tahun dan 43-51 tahun masing-masing 9 orang atau 15,00 persen.

\section{Tingkat pendidikan}

Tingkat pendidikan seseorag akan mempengaruhi terhadap penerimaan dan temuan-tuan atau inovasi baru, demikian pula cara pengeolahan dasn pengembangan usahataninya. Semakin tinggi tingkat pendidikan baik formal maupun non formal diharapkan semakin rasaional pemeliharaanya dalam mengelola usahataninya. Hal ini berpengaruh terhadap pengambilan keputusan, apakah usaha tani yang 
dikelolanya menguntungkan atau tidak. Gambaran mengenai tingkat pendidikan petani jagung kuning di kecamatan Bontotiro dapat dilihat pada Tabel 8.

Tabel 4. Jumlah Responden, Berdasarkan Tingkat Pendidikan di Kecamatan Bontotiro, Kabupaten Bulukumba, 2005.

\begin{tabular}{cccc}
\hline No & $\begin{array}{c}\text { Tingkat } \\
\text { Pendidikan }\end{array}$ & $\begin{array}{c}\text { Jumlah } \\
\text { Responden } \\
\text { (Orang) }\end{array}$ & $\begin{array}{c}\text { Presentase } \\
(\%)\end{array}$ \\
\hline 1 & $\begin{array}{c}\text { Tidak pernah } \\
\text { sekolah }\end{array}$ & 25 & 40,00 \\
\hline 2 & SD & 12 & 20,00 \\
\hline 3 & SMP & 15 & 25,00 \\
\hline 4 & SMA & 9 & 15,00 \\
\hline & Jumlah & 100,00 & 60 \\
\hline
\end{tabular}

Dari Table 4 terlihat bahwa tingkat pendidikan petani responden yang tidak pernah sekolah sebanyak 24 orang atau 40,00 persen, jumlah responden yang memiliki tingkat pendidikan SD sebanyak 12 orang atau 25,00 persen dan jumlah responden dengan tingkat pendidikan SD sebanyak 12 orang atau 25,00 persen dan jumlah responden dengan tingkat pendidikan SMP sebanyak 15 orang atau 20,00 persen sedangkan responden yang tingakat pendidikan SMA sebanyak 9 orang atau 15,00 persen.

Untuk melihat hubungan anatara tingkat pendidikan dengan pendapatan petani jagung kuning dapat dilihat pada Tabel 9.

Tabel 5. Hubungan antara tingkat pendidikan dengan pendapatan petani jagung kuning di Kecamatan Bontotiro,Kabupaten Bulukumba, 2005.

\begin{tabular}{cccccc}
\hline \multirow{2}{*}{ No } & pendidikan & \multicolumn{3}{c}{ Pendapatan Responden } & \multirow{2}{*}{ Jumlah } \\
\cline { 3 - 5 } & Rendah & Sedang & Tinggi & \\
\hline 1 & $\begin{array}{c}\text { Tidak } \\
\text { Sekolah }\end{array}$ & 11 & 11 & 2 & 24 \\
\hline 2 & SD & 7 & 4 & 1 & 12 \\
\hline 3 & SMP & 11 & - & 4 & 15 \\
\hline 4 & SMA & 5 & 3 & 1 & 9 \\
\hline & Total & 34 & 18 & 8 & 60 \\
\hline
\end{tabular}

Sumber : Data Primer Setelah Diolah, 2005.

Dari Tabel 5 menunjukkan bahwa responden yang berpendidikan SD dengan pendapatan tertinggi sebanyak 4 orang atau 6,67 persen, responden yang tidak sekolah sebanyak 11 orang atau 18,33 persen yang berpendapat sedang serta yang berpendidikan tidak sekolah dan SMP masing-masing 11 orang atau 18,33 persen yang berpendapat rendah.

\section{Jumlah Tanggungan Keluarga Petani Responden}

Jumlah tanggungan keluarga merupakan potensi sumberdaya yang dimiliki oleh petani terutama terhadap ketersediaan tenaga kerja, namun dilain pihak dapat menjadi beban ekonomi bagi petani yang memiliki sumberdaya modal dan lahan yang terbatas.

Tanggungan keluarga yang dimaksud disiniadalah semua orang yang ditanggung oleh kepala keluarga dalam hal ini petani sampel. Banyaknya tanggungan keluarga petani responden dapat dilihat pada Tabel 6 .

Tabel 6. Jumlah petani berdasarkan jumlah tanggungan keluarga di Kecamatan Bontotiro, Kabupaten Bulukumba, 2005.

\begin{tabular}{cccc}
\hline No & $\begin{array}{c}\text { Jumlah } \\
\text { tanggungan } \\
\text { keluarga (orang) }\end{array}$ & $\begin{array}{c}\text { Jumlah } \\
\text { petani } \\
\text { (Orang) }\end{array}$ & $\begin{array}{c}\text { Presentase } \\
(\%)\end{array}$ \\
\hline 1 & $1-2$ & 6 & 10,00 \\
\hline 2 & $3-4$ & 40 & 66,67 \\
\hline 3 & $5-7$ & 14 & 23,33 \\
\hline & Jumlah & 60 & 100,00 \\
\hline
\end{tabular}

Tabel 6 dapat dilihat jumlah tanggungan keluarga berkisar antara 1 sampai dengan 7 orang. Jumlah anggota keluarga petani yang terbanayk adalah 3-4 orang yaitu 40 orang atau 66,67 persen. Pada umumnya anggota keluarga responden di Kecamatan Bontotiro tergolong dalam umur produktif sehingga dapat dijadikan sebagai sumber tenaga kerja dalam usahatani jagung kuning. Dengan demikian kebutuhan akan tenaga kerja dapat dipenuhi dari dalam keluarga sehingga secara langsung dapat mengurangi pengeluaran tunai untuk tenaga kerja. Untuk lebih jelasnya dapat dijelaskan mengenai jumlah tenaga kerja keluarga responden dapat dilihat pada Tabel 7.

Tabel 7. Jumlah Responden Berdasarkan Jumlah Tenaga Kerja Keluarga di Kecamatan Bontotiro, Kabupaten Bulukumba, 2005.

\begin{tabular}{llll}
\hline No & Jumlah & Jumlah & Presentase \\
\hline
\end{tabular}




\begin{tabular}{cccc}
\hline & $\begin{array}{c}\text { tanggungan } \\
\text { keluarga (orang) }\end{array}$ & $\begin{array}{c}\text { petani } \\
\text { (Orang) }\end{array}$ & $\mathbf{( \% )}$ \\
\hline 1 & $1-2$ & 11 & 18,33 \\
\hline 2 & $3-4$ & 42 & 70,00 \\
\hline 3 & $5-6$ & 7 & 11,67 \\
\hline & Jumlah & 60 & 100,00 \\
\hline
\end{tabular}

Dari Tabel 7 dijelaskan bahwa jumlah tenaga kerja keluarga 3-4 orang sebanyak 42 responden atau responden atau 70,00 persen dan jumlah tenaga kerja keluarga 5-6 orang sebanyak 7 responden atau 11,67 persen. Untuk mengetahui hubungan antara tenaga kerja keluarga dengan pendapatan petani dapat dilihat pada tabel 12 .

Tabel 8. Tabungan antara tenaga keluarga dengan pendapatan petani jagung kuning di Kecamatan Bontotiro, Kabupaten Bulukumba, 2005.

\begin{tabular}{cccccc}
\hline & \multirow{2}{*}{$\begin{array}{c}\text { Tenaga } \\
\text { Nerja } \\
\text { No }\end{array}$} & \multicolumn{3}{c}{ Pendapatan Responden } & Jumlah \\
\cline { 3 - 5 } & $\begin{array}{c}\text { dalam } \\
\text { keluarga }\end{array}$ & Rendah & Sedang & Tinggi & \\
\hline 1 & $1-2$ & 6 & 5 & 6 & 10,00 \\
\hline 2 & $3-4$ & 25 & 13 & 40 & 66,67 \\
\hline 3 & $5-7$ & 3 & - & 14 & 23,33 \\
\hline & Jumlah & 34 & 18 & 60 & 100,00 \\
\hline
\end{tabular}

Sumber : Data Primer setelah Diolah, 2005.

Dari Tabel 8 menunjukkan bahwa responden tenaga kerja keluarga 3-4 orang dan 5-6 orang masingmasing 4 responden yang berpendapatan tinggi, tenaga kerja keluarga 3-4 orang sebanyak 13 responden yang berpendapatan sedang, dan tenaga kerja keluarga 3-4 orang sebanyak 25 responden.

\section{Pengalaman Berusahatani}

Pengalaman berusahatani merupakan salah satu faktor yang berpengaruh terhadap kemampuan bekerja dan berfikir dalam mengelola usaha taninya. Pengalaman usaha tani yang dimaksud adalah sejak petani mulai menggarap lahan membantu orang tuanya hingga mampu mengusahakan usahanya sendiri. Pada umumnya petani yang memilki pengalaman usahatani cukup lama cenderung memiliki pula kemampuan berusatani labih baik dibandingkan dengan petani yang kurang berpengalaman dalam berusahatani. Gambaran mengenai pengalaman berusahatani petani responden dapat dilihat pada Tabel 9.

Agrovital | Jurnal Ilmu Pertanian Universitas Al Asyariah
Tabel 9. Jumlah petani responden berdasarkan pengalaman berusahatani di Kecamatan Bontotiro, Kabupaten Bulukumba, 2005.

\begin{tabular}{cccc}
\hline No & $\begin{array}{c}\text { Pengalaman } \\
\text { Berusahatani } \\
\text { (Tahun) }\end{array}$ & $\begin{array}{c}\text { Jumlah } \\
\text { petani } \\
\text { (Orang) }\end{array}$ & $\begin{array}{c}\text { Presentase } \\
(\%)\end{array}$ \\
\hline 1 & $10-21$ & 29 & 48,33 \\
\hline 2 & $22-33$ & 13 & 21,67 \\
\hline 3 & $34-47$ & 18 & 30,00 \\
\hline & Jumlah & 60 & 100,00 \\
\hline
\end{tabular}

Dari Tabel 9 dapat dijelaskan bahwa pengalaman berusahatani responden petani jagung kuning berkisar anatara 10-21 tahun. Pengalaman berusahatani cukup memadau sehingga dapat dijadikan sebagai penunjang dalam pengembangan komoditi jagung kuning di Kecamatan Bontotiro, karena tanaman jagung kuning ini merupakan tanaman pokok yang diusahakan oleh petani

Tabel 10. Hubungan antara pengalaman berusatani dengan pendapatan petani jagung kuning di Kecamatan Bontotiro, Kabupaten Bulukumba, 2005.

\begin{tabular}{cccccc}
\hline \multirow{2}{*}{ No } & Pengalaman & \multicolumn{3}{c}{ Pendapatan Responden } & \multirow{2}{*}{ Jumlah } \\
\cline { 3 - 5 } & usahatani & Rendah & Sedang & Tinggi & \\
\hline 1 & $10-21$ & 19 & 5 & 5 & 29 \\
\hline 2 & $22-33$ & 5 & 6 & 2 & 13 \\
\hline 3 & $34-47$ & 10 & 7 & 1 & 18 \\
\hline & Total & 34 & 18 & 8 & 60 \\
\hline
\end{tabular}

Sumber : data Primer Setelah diolah,2005.

Dari Tabel 10 menunjukkan bahwa responden yang berpengalaman berusahatani 10-21 tahun sebanyak 5 orang atau 8,33 persen berpendapatan tinggi, responden yang berpengalaman berusahatani 34-47 tahun sebanyak 7 orang yang berpendapatan sedang, dan responden yang berpengalaman berusahatani 10-21 tahun sebanyak 19 orang atau 31,67 persen yang berpendapatan rendah.

\section{Luas Areal Pertanaman Petani}

Luas areal pertanaman akan mempengaruhi efisiensi atau tidaknya suatu usaha pertanian, karena sangat erat hubungannya dengan biaya yang akan dikeluarkan dan jumlah produksi yang akan dihasilkan. Semakin luas areal pertanaman biaya produksi yang dikeluarkan juga semakin besar. Untuk 
mengetahui luas areal pertanaman petani responden di Kecamatan Bontotiro dapat dilihat pada Tabel 11.

Tabel 11. Jumlah Petani Responden Menurut Luas Areal Pertanaman di Kecamatan Bontotiro, Kabupaten Bulukumba, 2005.

\begin{tabular}{cccc}
\hline No & Luas lahan(ha) & $\begin{array}{c}\text { Jumlah } \\
\text { petani } \\
\text { (Orang) }\end{array}$ & $\begin{array}{c}\text { Presentase } \\
(\%)\end{array}$ \\
\hline 1 & $0,25-1,16$ & 29 & 48,33 \\
\hline 2 & $1,17-2,08$ & 14 & 23,33 \\
\hline 3 & $2,09-3,00$ & 17 & 28,34 \\
\hline & Jumlah & 60 & 100,00 \\
\hline
\end{tabular}

Sumber: Data Primer setelah Diolah, 2005.

Dari Tabel 11 dapat dilihat bahwa luas areal pertanaman petani responden yaitu bersekitar 0,251,16 hektar sebanyak 29 orang atau 48,33 persen, luas areal pertanaman 2,09-3,00 hektar sebanyak 17 orang atau 28,34 persen dan yang paling sedikit adalah luas areal pertanaman 1,17-2,08 hektar adalah sebanyak 14 orang atau 23,33 persen.Untuk melihat hubungan anatara luas areal pertanaman dengan pendapatan petani jagung kuning dapat dilihat pada Tabel 12 .

Tabel 12. Hubungan antara luas areal pertanaman dengan pendapatan petani jagung kuning di Kecamatan Bontotiro, Kabupaten Bulukumba, 2005.

\begin{tabular}{cccccc}
\hline & $\begin{array}{c}\text { Luas } \\
\text { No }\end{array}$ & \multicolumn{3}{c}{ Pendapatan (Rp) } & \multirow{2}{*}{ Jumlah } \\
\cline { 3 - 5 } & (ha) & Rendah & Sedang & Tinggi & \\
\hline 1 & $\begin{array}{c}0,25- \\
1.16\end{array}$ & 29 & - & - & 29 \\
\hline 2 & $\begin{array}{c}1,17- \\
2,08\end{array}$ & - & 14 & - & 14 \\
\hline 3 & $\begin{array}{c}2,09- \\
3,00\end{array}$ & 5 & 4 & 8 & 17 \\
\hline & Total & 34 & 18 & 8 & 60 \\
\hline
\end{tabular}

Sumber : Data Primer setelah Diolah, 2005.

Dari Tabel 12 menunjukkan bahw aresponden yang mempunyai luas lahan 2,09-3,00 ha sebanyak 8 orang atau 13,33 yang berpendapatan tinggi, responden yang mempunyai luas lahan, 1,172,08 ha sebanyak 14 orang atau 23,33 persen yang berpendapatan sedang, dan responden yang

Agrovital | Jurnal Ilmu Pertanian Universitas Al Asyariah mempunyai luas lahan $0,25-1,16$ ha sebanyak 29 orang atau 48,33 persen yang berpendapatan rendah.

\section{A. Analisis Pendapatan}

Analisis pendapatan suatu sistem usahatani adalah bertujuan untuk mengetahui keuntungan yang diperoleh dalam berusahatani yang diukur berdasarkan besarnya R/C-ratio dan B/C-ratio merupakan perbandingan antara nilai produksi (penerimaan) dengan total biaya usahatani yang digunakan. Penerimaan tunai yang diperoleh dari penjualan seluruh hasil produksi pemusim tanam, sedangkan biaya total produksi adalah seluruh biaya yang digunakan untuk membeli sarana produksi dan biaya tenaga kerja setiap musim tanam.

Analisis pendapatan usahatani dilakukan dalam kajian adalah usahatani jagung kuning. Tingkat pendapatan petani diukur berdasarkan penerimaan yang diterima dari hasil penjualan jagung kuning denga seluruh biaya yang dikeluarkan pada musim tanam tersebut. Untuk mengetahui rata-rata tingkat pendapatan petani responden dalam satu musim tanam perhekta dapat dilihat pada Tabel 13.

Tabel 13. Pendapatan rata-rata petani jagung kuning permusim tanaman di Kecamatan Bontotiro, Kabupaten Bulukumba, tahun 2005 .

\begin{tabular}{clc}
\hline No & \multicolumn{1}{c}{ Uraian } & Jumlah/nilai (Rp) \\
\hline 1 & Luas Lahan & 1 hektar \\
\hline 2 & Produksi & $2.753 .947 \mathrm{~kg} / \mathrm{ha}$ \\
\hline 3 & Produktivitas & $2.131,078 \mathrm{~kg} / \mathrm{ha}$ \\
\hline 4 & Harga & Rp. $750 / \mathrm{kg}$ pipilan \\
\hline 5 & Penerimaan (R) & Rp. $2.065 / 460.250$ \\
\hline 6 & $\begin{array}{l}\text { Total biaya } \\
\text { (TC) }\end{array}$ & Rp. 626.492.794 \\
\hline 7 & Pendapatan $(\pi)$ & Rp. $1.438 .967,456$ \\
\hline 8 & R/C Ratio & 3,2 \\
\hline & B/C Ratio & 2,2 \\
\hline
\end{tabular}

Sumber: Data Primer setelah Diolah, 2005.

Berdasarkan hasil perhitungan tersebut diatas, maka dapat diketahui bahwa rata-rata pendapatan petani jagung kuning permusim tanam per hektar adalah sebesar Rp 1.438,967,456. Sehingga dengan demikian dapat dinyatakan bahwa usahatani jagung kuning di Kecamatan Bontotiro memiliki prospek untuk dikembangkan atau diusahakan.

Untuk mengatahui apakah alokasi modal dan pembiayaan pada usaha tani jagung kuning tersebut menguntungkan atau layak untuk diusahakan, maka 
dilakukan analisis perbandingan revenue cost ratio, untuk membandingkan antara selisih besarnya nilai produksi dan besarnya nilai produksi. Semakin besar $\mathrm{R} / \mathrm{C}$ ratio uang diperoleh maka semakin menguntungkan usaha yang dilakukan.

Berdasarkan hasil analisis $\mathrm{R} / \mathrm{C}$ ratio diperoleh nilai sebesar 3,2.nilai dapat diinterpretasikan bahwa setiap Rp 1.000 biaya yang dikeluarkan oleh petani dalam usahanya maka akan memperoleh penerimaan sebesar $\mathrm{Rp}$ 3.200. dan nilai $\mathrm{B} / \mathrm{C}$ ratio diperoleh sebesar 2,2, maka usaha tersebut layak untuk diusahakan

Berdasarkan perspektif pendapatan, $\mathrm{R} / \mathrm{C}$ ratio dan $\mathrm{B} / \mathrm{C}$ ratio maka dapat dinyatakan bahwa usaha tadi jagung kuning yang dilakukan oleh petani responden layak untuk dikembangkan atau diusahakan terutama dalam relevansinya dengan upaya peningkatan pendapatan petani.

\section{B. Analisis Pemasaran}

\section{Saluran pemasaran jagung kuning}

Dalam kegiatan pemasaran atau saluran pemasaran jagung kuning dilokasi penelitian, pada umumnya para pedagang langsung mendatangi petani dan melakukan transaksi langsung. Selajutnya pedagang pengumpul tersebut menjual ke pedagang besar yang ada di Kabupaten Bulukumba, kemudian pedagang besar akan menjual ke makassar, pedagang pengecer dan juga konsumen.

Panjang pendeknya saluran pemasran yang dilalui oleh suatu produksi dapat menentukan besarnya margin totan yang diterima oleh lembaga pemasaran yang terlibat. Bagi petani yang menjual jagung kuningnya ke pedagang besar akan lebih menguntungkan dibanding jikamereka menjual kepedagang pengumpul. Tetapi karena pertimbangan mengenai jumlah produksi dan pedagang pengumpul langsung ketempat petani sehingga umumnyapetani menjual kepedagang pengumpul.

Pedagang pengumpul yang melakukan pembelian jagung kuning pada petani responden umumnya adalah warga setempat dengan pembelian $\mathrm{Rp} 750 / \mathrm{kg}$ jagung pipilan. Untuk pengangkutan jagung kuning tersebut pedagang pengumpul menggunakan mobil sendiri atau mobil sewa dengan biaya 5.000/kurang.

Pedagang besar dalam hal ini yaitu pedagang yang melakukang pembelian jagung kuning baik dari petani maupun dari pedagang pengumpul. Jagung kuning yang di beli oleh pedagang besar tarsebut tidal langsung habis terjual sehingga umumnya pedagang besar melakukan penyimpanan untuk menunggu pembeli.

Pedagang pengecer membeli jagung kuningdari pedagang besar dengan rata-rata harga $\mathrm{Rp}$
$1.300 / \mathrm{kg}$ pipilan. Kemudian pengecer tersebut menjualnya dengan harga $\mathrm{Rp} 1.700 / \mathrm{kg}$ pipilan.

\section{Margin, Biaya dan keuntungan}

Margin pemasaran jagung kuning adalah selisih antara harga penjualan dengan harga pembelian jagung kuning oleh lembaga pemasaran. Biaya pemasaran jagung kuning adalah biaya yang di keluarkan oleh lembaga pemasran dalam memasarakan jagung kuning tersebut meliputi : Biaya Transportasi, Biaya Penyimpanan, Biaya Sortasi atau grading. Keuntungan pemasaran jagung kuning adalah selisih anatara margin pemasaran dengan biaya pemasaran jagung kuning.

Untuk lebih jelasnya mengenai besarnya margun, biaya dan keuntungan pemasaran jagung kuning pada masing-masing lembaga yang terlibat dalam mendistribusikan jagung kuning dari petani ke konsumen dapat dilihat pada Tabel 14

\begin{tabular}{|c|c|c|c|c|c|c|c|}
\hline $\begin{array}{l}\text { Saluran } \\
\text { Pemasaran }\end{array}$ & $\begin{array}{l}\text { Lembaga } \\
\text { pemasaran }\end{array}$ & $\begin{array}{l}\text { Harga } \\
\text { jual } \\
\text { (Rp/Kg) }\end{array}$ & $\begin{array}{l}\text { Harga } \\
\text { pembeli } \\
\text { an } \\
\text { (Rp/Kg) }\end{array}$ & $\begin{array}{l}\text { Margin } \\
(\mathrm{Rp} / \mathrm{Kg})\end{array}$ & $\begin{array}{l}\text { Biaya } \\
(\mathrm{Rp} / \mathrm{Kg})\end{array}$ & $\begin{array}{l}\text { Keu } \\
\text { ntun } \\
\text { gan } \\
(\mathrm{Rp} / \\
\mathrm{Kg}) \\
\end{array}$ & $\begin{array}{l}\text { Presenta } \\
\text { se } \\
\text { Margin }\end{array}$ \\
\hline & \multirow{3}{*}{$\begin{array}{l}\text { Petani } \\
\text { pedagang } \\
\text { Pengump } \\
\text { ul } \\
\text { Pedagang } \\
\text { besar } \\
\text { Pedagang } \\
\text { pengecer } \\
\text { Jumlah }\end{array}$} & 750 & - & - & - & - & - \\
\hline & & 1000 & 750 & 250 & 85 & 165 & 26,32 \\
\hline & & 1300 & 1000 & 300 & 80 & 220 & 31,58 \\
\hline
\end{tabular}

$\begin{array}{llllll}1700 & 1300 & 400 & 60 & 340 & 42,10\end{array}$
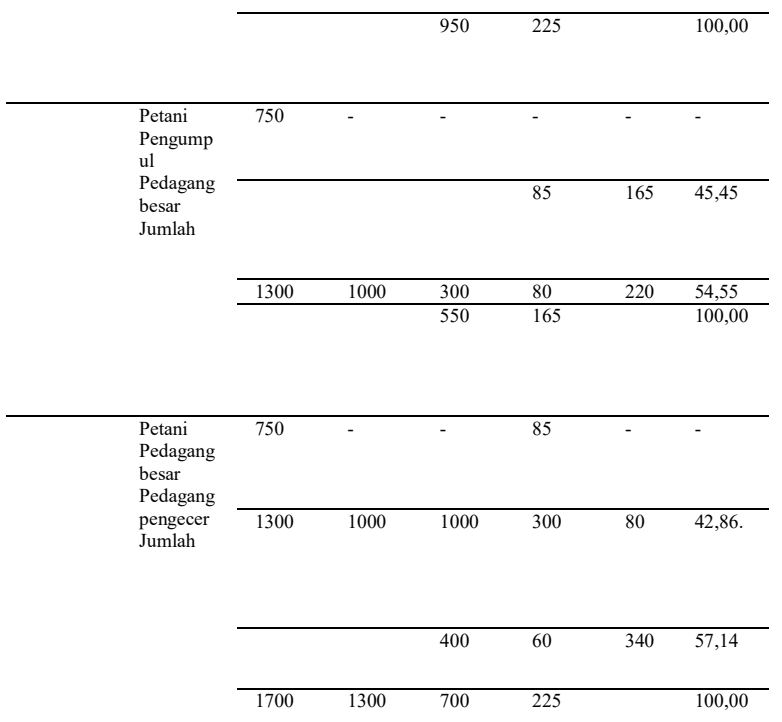


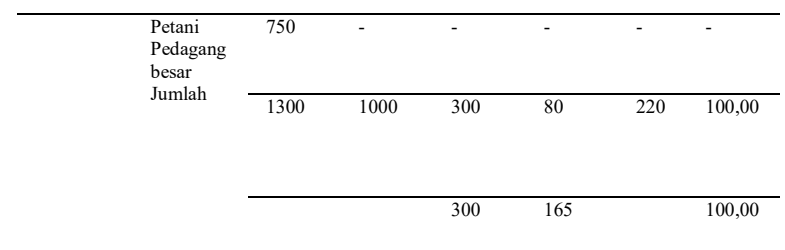

\section{Kesimpulan}

Berdasarkan hasil dan pembahasan yang telah diuraikan koma maka dapat ditarik suatu kesimpulan sebagai berikut :

1. Pendapatan yang diperoleh pertanyaan responden menguntungkan yaitu sekitar Rp. 1.438.967,456 dengan nilai $\mathrm{R} / \mathrm{C}$ - ratio sebesar 3,2 dan B/C-ratio sebesar 2,2 berarti layak untuk diusahakan atau dikembangkan titik

2. Margin pemasaran terbesar berturut-turut diterima oleh pedagang pengecer sebesar Rp. 400/kg jagung pipilan, pedagang besar sebesar $300 / \mathrm{kg}$ jagung pipilan dan pedagang pengumpul sebesar Rp. $250 / \mathrm{kg}$ jagung pipilan

\section{Daftar Pustaka}

AAK. 1993.Tekhnik Bercocok Tanam Jagung. Kanisius, Yogyakarta.

Adiwilaga. 1982. Ilmu Usahatani. Alumni, Bandung.

Adjid, D. A. 1994. Sistem Strategi Pengembangan Agribisnis. Badan Agribisnis Dapartemen Pertanian, Jakarta.

Bada Penelitian dan Pengembangan Pertanian. 1999. Rencana Strategi Badan Penelitian dan Pengembangan Pertanian 1999- 2004. Bada Litbang Pertanian. Dapartemen Pertanian, Jakarta.

Dinas Tanaman Pangan dan Hortikultura. 2003. Laporan Tahunan Kabupaten Bulukumba. Dinas Tanaman Pangan dan Hortikultura, Bulukumba.

Downey dan Ericksos. 1992. Managemen Agribsinis. Erlangga, Jakarta.

Farida. N, 1986. Pemasaran Produk Pertanian. Laphas UNHAS, Ujung Pandang.

Gumbira, I.S. 2000. Managemen Agribisnis. PT. Raja Grafindo Persada, Jakarta.

Hernanto, F. 1988. Ilmu Usahatani. PT Penebar Swadaya. Jakarta

Kadaria. 1981. Analisis Pendapatan Nasional. Ghalia Indonesia, Jakarta.
Kartasaputra. 1988. Pengantar Ekonomi Produksi Pertanian. PT. Bina Aksara, Jakarta.

Kotler, P. 1992. Managemen Pemasaran Analisis Perencanaan Implementasi dan Pengendalian. Salemba Empat, Jakarta.

Mosher, A.T. 1986. Penggerak dan Pembangunan Pertanian. Yasaguna, Jakarta.

Mubyarto. 1989. Pengantar Ekonomi Pertanian. LP3ES, Jakarta.

Mulyono, Sri. 2003. Statistik Untuk Ekonomi (Edisi Revisi). Lembaga Penerbit Fakultas Ekonomi Universitas Indonesia, Jakarta.

Purmaningrum. 2000. Pengantar Ekonomi Mikro.LPFE Trisaksi, Jakarta.

Rukmana, R. 1997. Usahatani Jagung. Kanisius, Yogyakarta.

Saefuddin, A.M. 1983. Pengkajian Pemasaran Komoditi Pertanian. Pascasarjana IPB, Bogor.

Salahuddin. 1988. Kebijaksanaan dan Strategi Pengembangan Agribisnis dan Agroindustri Sebagai Pemicu Pertumbuhan Ekonomi Sosial.Dapartemen Pertanian, Jakarta.

Saleh, K. 2001. Kumpulan Pemikir Agribisnis Paradigma Pembangunan Ekonomi Berbasis Pertanian. Pustaka Wirausaha Muda dan PT. Logi Griya, Bogor.

.2002. Suara Dari Bogor Membangun Sistem Agribisnis. Pustaka Wirausaha Muda dan PT. Logi Griya, Bogor.

Soehardjo dan Patong. 1987 Sendi-sendi Pokok Ilmu Usaha Tani. LEPHAS, Ujung Pandang.

Soekartawi. 1993. Prinsip Dasar Ekonomi Pertanian (Teori dan Aplikasinya). PT. Raja Grafindo Persada, Jakarta.

.1996. Ilmu Usaha Tani an Pengembangan Petani Kecil. Universitas Indonesia Press, Jakarta.

.2002. Analisis Usaha Tani. Universitas Indonesia Press, Jakarta. .2002a. Prinsip Dasar Managemen Pemasaran Hasil-hasil Pertanian (Teori dan Aplikasinya). Cetakan Ketiga. PT. Raja Grafindo Persada, Jakarta.

Warisno. 1988. Budidaya Jagung Hibrida. Konsius, Yogyakarta.

Yasin, Moh. 1991. Dasar-dasar Demografi. Lembaga Penerbit Fakultas Ekonomi Universitas Indonesia, Jakarta. 